have a very real responsibility for the successful outcome of the new Bill. The key to success can be stated in a single word: personnel. Personnel for administration, technology and research. The production of suitable candidates for the many and varied jobs is the task of the schools and universities. In these days it is one beset with difficulties, and it may well be that some years must elapse before suitable staff for some of the research posts, for example, in biology, can be produced. But the task lies clearly before us. The sooner we begin, the better for the welfare of the British Colonies.

\section{Science, Poetry and Religion}

Three lectures delivered by Mr. Geoffrey Hoyland at Woodbrooke Summer School in 1944 have now been printed as a challenging and picturesquely written booklet entitled "The Tyranny of Mathematies" (S.C.M. Press, Ltd., 56 Bloomsbury Street, London, W.C.1. Pp. 52. 1s. 6d. net). Mr. Hoyland's theme is the age-old dichotomy between the emotional and the rational approach to human problems; but his treatment is fresh, partly owing to his vivid style, and partly because it is unusual to find a religious apologist with a good knowledge of science and mathematics. It is not possible here even to summarize his arguments and exhortations. His conclusion, briefly, is that since the Renaissance, and particularly since Newton and Leibniz added the weapon of the calculus to the armoury of the man of science, we have worshipped at the analytical shrine of mathematics, to the exclusion of the true gods of poetry and religion, which, with science as their handmaid, can alone reveal to us the whole truth about the universe. "If our sick world is to be saved the lover and the poet must take control."

Few men of science will go the whole way with Mr. Hoyland, preferring to believe that a constantly adjusted partnership between the emotional and rational elements in life, rather than the supremacy of either over the other, is the most fruitful treatment of the dichotomy (and indeed the only one that would justify the use of the word 'symbiosis' in the subtitle); but many will be stimulated by this keen analysis of the problems involved, and enjoy the colourful language in which it is couched.

\section{Cultivation of Rhubarb}

RHUBARB is one of the oldest cultivated plants, for its history in China, its native home, dates back to almost 3000 B.C. At first it was grown solely for the medicinal properties of its roots and was introduced into England from Siberia on that account some three hundred years ago. Later, interest developed in the edible properties of the leaf stalks, but it was not until the nineteenth century that plantings of rhubarb for culinary purposes became widespread. The literature on rhubarb cultivation is scanty, so the illustrated bulletin, compiled by $H$. V. Taylor and E. E. Skillman, recently issued by the Ministry of Agriculture (No. 113. H.M. Stationery Office. 9d.) should prove a great asset to growers. The advice given relates generally to normal peacetime practice. Only a limited number of varieties are grown for commercial purposes ; each is described in some detail and attention directed to the fact that all may be seen growing in the gardens of the Royal Horticultural Society at Wisley. The chief area of production is the West Riding of Yorkshire, though in Essex, Lancashire and Cheshire quite a considerable acreage is devoted to the crop. The high rain- fall, acid soil and the capacity of the plant to withstand smoke pollution contribute to the success of the crop in the Leeds district; in fact the contaminated atmosphere is an asset for forcing purposes, as it induces premature leaf shedding and early dormancy. The cultivation of both forced and natural rhubarb are described at some length and a section devoted to grading, packing and marketing. As regards diseases, that termed 'crown rot' appears to cause most trouble. Eelworm infection is now thought to be largely responsible for this, though it is not yet clear whether there are not also other factors which contribute to this condition.

\section{Plea for a Museum for Croydon}

DR. H. W. Dickinson's presidential address this year to the Croydon Natural History and Science Society discussed the proposal for a museum for the district. Croydon is the largest borough in Great Britain without an adequate museum service, and he stated that the Society is now urging the proposal upon the local authority "as one of the particular objects to be carried into effect in the post-war municipal reconstruction scheme". If the museum materializes, he stressed the importance of a localized. policy, and in this connexion suggested that a plan already exists in the form of the Society's Regional Survey of the district. Alluding to museum functions, he placed 'research' before 'visual education', but in view of the present-day urgent need for all forms of education, the smaller regional museums might usefully reverse this order. Dr. Dickinson justifiably deprecated the use of old dwelling-houses for museum purposes, for these do not provide the offices and facilities required for the execution of a useful and progressive service. Referring to the reluctance of municipalities "to spend money on buildings even if they own valuable collections", he reminded the audience that the Nuffield Trust, and the Carnegie United Kingdom Trust, could be approached for financial help. Clearly, Dr. Dickinson has closely studied Markham's report on "The Museums and Art Galleries of the British Isles" (1938), and all authorities undertaking the establishment or reorganization of regional museums in the future could profitably follow his example.

\section{The Cinema}

Mr. Lindaren's pamphlet "The Cinema" (English Universities Press, Ltd. 4d. net) well maintains the standard set in this Handbook for Discussion Groups series, and should serve as a useful basis for discussion of various aspects of the cinema, including the Report of the Board of Trade Committee on Tendencies to Monopoly in the Cinematograph Film Industry, of which little has been heard since its publication. This particular aspect is indirectly touched by one of the subjects listed for discussion, but in the brief compass of nineteen pages Mr. Lindgren contrives to supply a good deal of background and to indicate most of the broader issues involved, such as the possibilities of the cinema in scientific research, education, the recording of history, the promotion of international understanding and the field of public information. $\mathrm{He}$ touches succinctly on the general problems of the entertainment value of the cinema, its influence and the question of censorship, where in two brief paragraphs he brings out the essential weaknesses and dangers inherent in censorship, and incidentally supplies adequate justification for the attempt to stimulate further discussion 
of the whole problem. There is an eminently practical note in the whole pamphlet, and if a word of criticism is called for, it is that the bibliography, even within the limits set, might have been improved.

\section{The Cooper Union: Annual Report}

The report of the Director of the Cooper Union, of New York, for the year ending June 30, 1944, covering the eighty-fifth year of the Institution, indicates that, although in some respects the disturbance of education in the United States under the impact of war has been less profound than in Great Britain, the problems of demobilization and of retraining are being faced along similar lines. There is an interesting parallel between educational thought, as portrayed in this report, in the two countries. Stress is laid upon the necessity of finding a strong and socially satisfying ethical foundation for modern education, on the limitations of the scientific method, and on the importance of no longer confining instruction and discussion in the human and spiritual values to the level of higher education and the liberal arts. The humanities and the social sciences should be brought into the curriculum of the high school, vocational school, junior college, technical institute and engineering school. The Department of Humanities of the Union has been successfully experimenting since 1939 with the integration of social and humanistic studies with the curricula of the schools of engineering and art, and is now offering a sequence of studies which, taken as a whole, should give a perspective of the history of Western culture and an appreciation of their roles as citizens and as individuals.

The report recognizes that the professional world of engineering and art properly demands a breadth and depth of preparation and a sophistication which cannot be gained by conventional class-room routine. The Cooper Union has been able to keep the nucleus of the teaching staff of its School of Engineering reasonably close to normal in the war period, and resumption of full teaching loads after the War can therefore be undertaken with speed and efficiency and with only minor additions to the staff. Policies to be followed with regard to the re-training of the demobilized and their integration into academic and social life are indicated, and a sub-committee of the Engineering Faculty has set itself the task of determining those qualities and attributes which should characterize the products of the four engineering curricula. Reference is also made to the work of the Student Health Service in educating the student in the use of the facilities already existing in the surrounding community, and of the Division of Social Philosophy, which completed its first decade during the year, in the field of adult education.

\section{Museums and Adult Education}

Av editorial article in the Australian Museum Magazine (June-August, 1944) directs attention to the contribution which museums have already made towards adult education. At the same time, it points out that there still remains the necessity for far greater extensions of the museums' services in this direction. It is suggested, for example, that museums should be available to the public out of ordinary working hours; that there should be better accommodation for study; and that there should be an increase of suitably qualified staff to guide and assist students.

\section{Society of Public Analysts and Other Analytical Chemists}

THE annual general meeting of the Society of Public Analysts and Other Analytical Chemists, held on March 9, marked the seventieth anniversary of the Society. In the past year the membership of the Society increased by 117 to 1,197 , and the circulation of the Society's journal, the Analyst, in spite of paper restriction, increased. In pursuance of the policy decided upon a year ago, the Society recently formed, within the framework of its constitution, two Groups concerned with particular branches of analysis, namely, the Microchemistry Group (chairman, Prof. H. V. A. Briscoe; hon. secretary, Mr. R. Belcher; present membership, 143) and the Physical Methods Group (chairman, Mr. R. C. Chirnside; hon. secretary, Dr. F. Wokes; present membership, 115). These Groups will hold meetings from time to time in London and elsewhere. The proceedings terminated with the presidential address of the retiring president, Mr. S. Ernest Melling, who, after reviewing some of the outstanding events of the past year in the Society's affairs, made some observations on the subject of water and water supplies. Dr. G. W. MonierWilliams was elected president for the present year.

\section{Science Masters' Association: Annual Meeting}

THE annual meeting of the Science Masters' Association will be held during April 9-11 at the City of London School. The president, Mr. C. L. Bryant, will speak on "The Impact of Science on Common Thought". The proceedings will include lectures by Dr. J. McG. Bruckshaw on "Physics and Economic Geology"; Mr. C. Bibby on "Health Education through School Biology"; "Penicillin", by Sir Alexander Fleming; "Scope and Limitations of the Science Teaching Film", by Mr. A. Elton (at the Ministry of Information Theatre); "The Electron Microscope", by Mr. F. W. Cuckow; "Chemistry of Plastics", by Mr. R. Maitland; and a discussion on "The Role of Science in the Future Educational System". There will also be the usual exhibitions. The third lecture on the Science and Citizenship Foundation will be delivered by Mr. J. G. Crowther, who will speak on "The Social Relations of Science" ; this lecture is open to the public, and tickets for visitors can be obtained from Mr. W. Ashhurst, Epsom College, Surrey.

\section{Announcements}

The Bristol Aeroplane Company has given $£ 60,000$ to the University of Bristol for the establishment of a Sir George White chair of aeronautical engineering, in memory of the founder of the Company.

THE Biochemical Society and the Nutrition Society have arranged a joint whole-day conference on "The Vitamin B-Complex", to be held on April 28, at the London School of Hygiene and Tropical Medicine, Keppel Street, W.C.1. Details of the programme will be published later.

Prof. James Mackintosh, dean of the London School of Hygiene and Tropical Medicine, is visiting Sweden to lecture for the British Council on aspects of social medicine and health education in Britain. He will probably also visit Finland. Prof. Mackintosh hopes to obtain in Sweden information for inclusion in a report on housing which he is preparing for the British Government. 